\title{
Discussion on Creation of TV Directors under the Background of Media Convergence
}

\author{
Xiao Peng \\ Shanghai Publishing and Printing College, Shanghai, China \\ Email:xp1212@163.com
}

How to cite this paper: Peng, X. (2018) Discussion on Creation of TV Directors under the Background of Media Convergence. Art and Design Review, 6, 71-75. https://doi.org/10.4236/adr.2018.62007

Received: April 16, 2018

Accepted: May 26, 2018

Published: May 29, 2018

Copyright $\odot 2018$ by author and Scientific Research Publishing Inc. This work is licensed under the Creative Commons Attribution International License (CC BY 4.0).

http://creativecommons.org/licenses/by/4.0/

\begin{abstract}
Rapid development of digital technique and network technique has accelerated convergence of various media, i.e., the convergence among paper media, TV media and other media. As the main force in creation of TV programs, the importance of TV directors is not to be ignored under the background of media convergence. Therefore, TV directors have to meet higher requirements. They should not only actively recognize and face modern fierce competition, but also enhance their own professional knowledge, skills and competence, and thus enrich the exhibition forms of TV arts. For this reason, the author has conducted analysis and discussion on creation of TV directors under the background of media convergence.
\end{abstract}

\section{Keywords}

Media Convergence, TV Directors, Creation, Skills

\section{Introduction}

The rapid development of network technique and modern digital technology has promoted close blending among different kinds of media to some extent and provided broad development space for TV media, but put forward higher requirements on TV directors at the same time. As emerging occupation, TV director has great importance. It derives from the development process of TV industry, assumes the tasks of communication, collaboration and practical operation, and has irreplaceable function no matter for TV programs or for TV media. The TV director's creative ability, to some degree, plays a decisive role in success of TV programs. Under the background of media convergence, TV directors should enhance their own professional knowledge, skills and competence more actively and enrich their creative skills, thus creating more excellent TV art pro- 
grams, as well as laying a solid foundation for future development of TV media.

\section{Importance of TV Directors under the Background of Media Convergence}

\subsection{Enrich Overall Connotation of the Programs}

TV directors play an indispensable role in development of modern industry, i.e., they should grasp scientifically, enhance work quality reasonably, and promote soundness of TV links. The development of modern TV programs calls for reasonable decisions and support of scientific evaluation on long development of TV contents, which needs combination with actual conditions of TV program's development, and reasonable formulation and enforcement of corresponding complete strategies (Li, 2015). Beyond all doubt, TV directors have great influence on it. Based on rapid development of modern digital technology and network technology, various media industries are able to progress better and faster. In addition, enrichment of the overall connotation of TV programs requires perfect the program content, and thus enable the TV media to give positive guidance on public opinions.

\subsection{Enrich Own Skills to Enhance Program Quality}

In addition to focus on its own development, TV program still need to play a leading role actively, i.e., reasonably drive and facilitate progress of surrounding media, which demands TV directors to continuously lift their own professional knowledge and skills; make continuous innovation and reform TV industry; and play a guiding and driving role, thus expediting the development of TV industry, elevate the quality of TV programs, and enrich the forms of the programs. Quick development of modern digital technology and network technology, to some extent, has promoted effective combination among various media. Moreover, media convergence has already become a trend for stable development of TV industry. In order to adapt to the development track of TV industry, we need to enrich the contents of TV programs to keep up with the times and give full play to the function of TV directors. TV creation requires for continuous enrichment of skills, active communication and combination with the media, and continuous enhancement of own knowledge and skills, thus facilitating further development of media.

\section{New Standards TV Directors Need to Be Equipped under the Background of Media Convergence}

To a certain degree, the rapid development of modern digital technology and network technology has accelerated profound innovation and reform of media industry environment. However, quick development of current society makes mankind enter the information era, under which the masses' cultural quality and aesthetic judgment have been promoted definitely, they gradually start to pursue spiritual and cultural demands, and they pay close attention to their own fates 
and the social environment (Wang, 2014). Without a doubt, these changes occurring depend on the environmental changes brought about by the development of TV media to a great extent. Better and faster development of TV media needs not only continuous expansion of space, but also continuous innovation and perfection of creative ideas. As for TV directors, they should play their roles more actively, make overall planning on creation of TV programs, grasp the general planned direction of TV programs, get familiar with the whole media business, dare to face various challenges brought about by information era to the media, and promote themselves to become highly qualified and highly skilled talents based on continuous development, i.e., be equipped with rich creative skills, grasp overall knowledge structure, and expand thinking modes, etc. Certainly, the development of TV programs calls for joint efforts of everyone, for the force of TV directors is limited. Therefore, TV directors should strengthen team communication and cooperation. Only when everyone join in the creative process actively can they really make innovation and enhance the creative skills of TV programs.

\section{Creative Skills TV Directors Need to Grasp under the Background of Media Convergence}

\subsection{Confirm TV Theme}

Compared with the subject matter or contents, the theme, also called as the main idea and basic concept, plays a more important role in leading the whole TV programs. It's known to us all that the title of a composition is the highlight of the whole article and contains rich ideological implication of the article. Such philosophy of "a good title is a good start of a good article" also applies to TV programs, i.e., a good title not only infuses new vitality to TV programs, but also makes the programs be more vivid and interesting. TV theme should be reasonable and scientific, and it has two basic requirements as follows.

Firstly, to seek truth from facts. The masses are main objects viewing TV programs. They are more interested in programs close to their own life or real events. Therefore the confirmation of TV theme needs full embodiment of surrounding life, combination of the reality, and rejects entirely groundless fiction. Of course, they can make reference to ancient legend, etc., but they should also seek truth during the creation, for unreal TV programs will not attract the masses or even may make them be repulsive to these utterly groundless TV contents.

Secondly, be interesting and new. Obsolete theme means that the contents are nothing new. Therefore, TV programs lacking novelty often fail to make the viewers feel the shock power of the TV theme, nor will they recommend others to watch the program. So, novelty is very important. However, novelty does not mean blind pursuit of shock power. TV directors need to connect the reality before creation. The theme needs support of creative thinking, on which basis the TV programs are able to attract the viewers. In recent years, TV series with antiwar 
theme are favorably loved by the viewers, but the timeworn story lines make them gradually lose confidence. Therefore novelty is very important for TV programs.

\subsection{Increase Approaches to Interact with the Viewers}

TV media belongs to traditional media, lacking interaction with the viewers. However, modern network media has improved this condition, i.e., strengthened the interaction. As a result, TV media should actively learn the approaches to interact with viewers basing on full understanding and grasp of network media, e.g., on-site interaction and telephone connection, etc. Currently, many variety shows actively interact with the viewers and have achieved a lot of fruits. Undoubtedly, to interact with viewers can win the love of them. Based on the variety shows, we're clearer about the positive function and significance of interacting with viewers. To a certain degree, viewers can be said to be the objects to be relied on by TV directors, so that TV directors should combine with actual psychological needs of the viewers when creating TV programs, as well as increase approaches to interact with the viewers, thus motivating the viewers and further enhancing viewer rating.

\subsection{Enrich Manifestation Styles of the Programs}

The manifestation styles of TV programs influence ratings of the programs imperceptibly. TV directors need to continuously enrich the manifestation styles of TV programs, i.e., not to be stereotyped or to be too simple. This will broaden the viewers' horizons to a certain degree. Documentary style is a good choice, for it can reinforce reality of the program, enhance the viewers' trust, make them be able to go deep into the TV scene, and achieve good effect. The TV programs have various kinds, mainly including music type, entertainment type, viewing type, etc. Facing these multiple types, TV directors need to retain the characteristics of each kind of TV program and not to make these features gradually disappear with the media convergence. TV directors need to choose diversified manifestation means to enrich the exhibition styles of TV programs, for reasonable and effective exhibition styles will bring different visual experience to viewers.

\section{Conclusion}

To sum up, to improve the TV directors' creative ability means a lot for modern media. However, modern media is in a complicated era when the in-depth convergence of various media has brought about a lot of challenges in spite of the good opportunities. So, in order to make the contents of TV programs be adapted to modern technical requirements, TV directors not only need to take corresponding measures according to the program contents, but also continuously enhance their own creative enthusiasm, guarantee quality of the TV programs, and enrich their own TV creative skills, as well as reasonably grasp the development chances and positively face the challenges, thus creating more 
better TV programs, enriching people's spiritual culture, and contributing their own force for harmonious development of the society.

\section{References}

Li, H. P. (2015). On Creative Skills of TV Directors under the Background of Media Convergence. Tribune of News Research, No. 12, 209.

Wang, Y. R. (2014). Creative Skills of TV Directors under the Background of Media Convergence. Art Science and Technology, No. 12, 67. 